Дерікот О.Ю., старший викладач кафедри стратегії національної безпеки та оборони НУО Украйни імені Івана Черняховського (м. Kuїв);

Клименко В.С., кандидат політичних наук, доиент, дочент кафедри стратегіі національної безпеки та оборони НУО України імені Івана Черняховського (м. Киї);

Козинець І.П., кандидат історичних наук, старший науковий співробітник, професор кафедри стратегії нащіональної безпеки та оборони НУО Украӥни імені Івана Черняховського (м. Київ)

\title{
СПІВРОБІТНИЦТВО ЗБРОЙНИХ СИЛ УКРАЇНИ 3 НАТО: ДОСВІД МИНУЛОГО ТА ПЕРСПЕКТИВА НА МАЙБУТНЄ
}

У статті розкривається співробітництво Збройних Сил Украйни з НАТО на кожному з визначених етапів. Проаналізовано нормативно-правову базу співпраці з Альянсом та розкрито позитивний характер військовополітичного співробітництва в інтересах міжнародної безпеки.

Ключові слова: Збройні Сили Украӥни, НАТО, співробітництво, позаблоковий статус, євроатлантична інтеграиія, програма "Партнерство заради миру".

Актуальність теми. Розвиток співробітництва України з Організацією Північноатлантичного договору (НАТО) - один із вирішальних напрямів безпекової політики нашої держави. Події, ящо відбуваються на Сході України у зв'язку із російською агресією, стосуються не лише самої України, а й є викликом для усіх країн-членів Альянсу. Як відзначив саміт НАТО у Варшаві (8-9 липня 2016 р.), “...Незалежна, суверенна і стабільна Україна, що твердо стоїть на засадах демократії та верховенства права, є запорукою 
євроатлантичної безпеки. Ми твердо підтримуємо суверенітет України, іiі територіальну цілісність в межах міжнародновизнаних кордонів і ii невід'ємне право визначати своє майбутнє та зовнішньополітичний курс без зовнішнього втручання...” [1, п. 16]. У зв'язку з цим підтверджено рішуче прагнення і надалі розвивати особливе партнерство між НАТО і Україною. “Незалежна, суверенна і стабільна Україна, повністю віддана демократії і верховенству права є ключем до європейської безпеки" - таке бачення ролі нашої країни з боку євроатлантичної спільноти [1, п. 24].

Мета статті - проаналізувати еволюцію відносин і стан співробітництва між Збройними Силами України і НАТО, систему співпраці та іï перспективу в умовах загострення відносин із Росією.

Історично склалось так, що співпраця 3 Організацією Північноатлантичного договору формувалась як пріоритетний напрям у системі міжнародних зв'язків України. У динаміці пошуків шляхів забезпечення національної безпеки у нових геополітичних умовах молода незалежна держава не могла не скористатися можливістю мати надійну опору міжнародних структур. Найбільш успішною воєнно-політичною організацією була і в сучасних умовах залишається Організація Північноатлантичного договору. Ретроспективний аналіз відносин України 3 НАТО дає змогу зробити позитивні висновки щодо ролі воєнно-політичного співробітництва в утвердженні нашої держави як суб'єкта європейської безпеки. Історія співпраці України з НАТО свідчить, що процес їх воєннополітичних відносин характеризувався послідовним поглибленням взаємодії, і це дає можливість розглядати цей процес поетапно. Більшість експертів виділяють такі етапи:

1) становлення відносин (1991-1996 pp.);

2) формування особливого партнерства (1997-2002 рр.);

3) поглиблення і активізація співробітництва (2002-2004рр.);

4) інтенсифікований діалог між Україною і НАТО (2005-2009рр.);

5) прагматичне співробітництво (2010-2013 рр.); 
6) посилена співпраця з подальшою інтеграцією (2014-2019рр.) [2].

Прагматичний етап взаємовідносин розпочався 32010 року після проголошення Україною позаблокового статусу. В Законі України “Про засади внутрішньої і зовнішньої політики“ Україна обрала для себе “...продовження конструктивного партнерства 3 Організацією Північноатлантичного договору та іншими військово-політичними блоками 3 усіх питань, що становлять взаємний інтерес...” [11]. Проте прийняття Україною позаблокового статусу не врятувало ii від агресії Російської Федерації. Тому 23 грудня 2014 року Україна відмовилася від цього “незрозумілого статусу", а 7 лютого 2019 року Верховна Рада України конституційною більшістю прийняла зміни в Конституцію України, в яких зазначено, що “...підтверджуючи європейську ідентичність Українського народу і незворотність європейського та євроатлантичного курсу України...” наша держава проголошує незворотність курсу на вступ до Організації Північноатлантичного договору [12].

Кожен із етапів має свої особливості з точки зору намірів, змісту i характеру двосторонніх відносин. Ці особливості визначалися підходами державного керівництва до співпраці 3 Брюсселем, зовнішніми та внутрішніми факторами. На кожному етапі визначалася роль ЗС України у співпраці з Альянсом для підвищення рівня їх боєздатності і взаємодії зі збройними силами країн-партнерів.

Еволюція відносин дає можливість стверджувати про позитивний характер воєнно-політичного співробітництва, взаєморозуміння і намагання діяти в інтересах міжнародної безпеки. Так, формуючи співробітництво 3 НАТО на першому етапі (1991-1996 рр.), Україна мала на меті забезпечити свою незалежність, територіальну цілісність, зміцнити національну безпеку, запобігти виникненню нових загроз стабільності і безпеці на європейському континенті та використати досвід і допомогу держав-членів Альянсу в реформуванні оборонної та інших пов'язаних з нею сфер. Ці наміри України знайшли повне розуміння і підтримку з боку Альянсу. 
На другому етапі (1997-2002 рр.) Хартія про особливе партнерство між Україною та НАТО, підписана 9 липня 1997 року у Мадриді, визначила новий характер відносин та додаткові напрями розвитку співробітництва 3 Альянсом, його принципи та механізми реалізації. Були напрацьовані різноманітні форми взаємодії з НАТО у найважливіших сферах (Комісія Україна - НАТО, місія України при НАТО, офіс зв'язку НАТО в Україні, Державні програми співробітництва України з НАТО, а також проведення візитів на високому рівні, консультацій, переговорів, симпозіумів, семінарів, досліджень, діяльності робочих груп тощо).

На третьому етапі (2002-2004 рр.) було прийнято “Державну стратегію щодо НАТО”, План дій Україна - НАТО, визначено новий рівень співпраці курс на інтеграцію України до Альянсу. Його реалізації сприяв процес розширення НАТО, коли ії членами стали безпосередні сусіди України Польща, Словаччина, країни Балтії,що були зацікавлені у приєднанні іï до цієї організації. Співробітництво України з НАТО набувало нового характеру через тісні зв'язки 3 цими країнами i їх збройними силами у воєннополітичній сфері, вивчення їх досвіду підготовки до членства в Альянсі.

Інтенсифікований діалог з НАТО (2005-2009 рр.) відкрив пряму можливість набуття членства України в цій організації і відповідної трансформації 3С України. Більш конкретний і цілеспрямований характер набули Річні цільові плани Україна-НАТО. Інтенсивним стали двосторонні відносини з країнами-членами Альянсу. Реалізації можливості отримати план дій щодо членства в НАТО (ПДЧ) завадила відсутність єдиної позиції провідних політичних сил України в розумінні національних інтересів країни.

Історичний процес взаємодії України 3 НАТО носив досить багатогранний характер, стосувався багатьох сфер життєдіяльності держави. У даній статті автори зосередилися, в основному, на співробітництві ЗС України з НАТО. У процесі співпраці України та їі Збройних Сил з Альянсом сформувалась відповідна система. До цієї системи можна віднести 
нормативно-правову базу та структуру органів управління, що відповідали за проведення міжнародного співробітництва Збройних Сил України, а також механізми співпраці з НАТО.

Сталою за цей період була тенденція зростання кількості прийнятих нормативно-правових документів як віддзеркалення потреби забезпечення співпраці 3С України з НАТО на етапах Пї розвитку Йдеться як про міжнародні, так і державні документи. Їх нараховується більше 40: на першому етапі - 6; на другому - 9; на третьому -20 , на четвертому -8 . Це сприяло активізації, розширенню сфер співробітництва, підвищенню ролі і авторитету Збройних Сил України.

Так, програма НАТО “Партнерство заради миру” (ПЗМ) відкривала шлях безпосереднього співробітництва ЗС України 3 Організацією Північноатлантичного договору. Окрім політичних цілей, вона визначала безпосередньо військові заходи, що планувалося здійснити для їх досягнення, а також сили і засоби, що виділяли ЗС України для участі у ПЗМ [3]. Таку сукупність сил і засобів утворювали спеціальні групи офіцерів, окремі підрозділи, кораблі, ескадрильї, полігони. Загальна чисельність виділеного особового складу перевищувала 2500 осіб [4]. На підтримку полігонів ЗС України у робочому стані за рахунок НАТО і США виділено близько 3,5 млн дол. Це було вкрай необхідно у зв'язку з відсутністю відповідного державного фінансування. За допомогою партнерів були створені 4 лабораторії з вивчення іноземних мов. Щодо характеру участі ЗС України у програмі ПЗМ переконливо свідчать матеріали архіву Верховної Ради України. Представники ЗС України за 1994-1999 роки брали участь у 469 різних заходах (70 з них у навчаннях). До занять на 130 курсах (35 - 3 миротворчої тематики, 32 - для штабних офіцерів, 35 - за фахом, 28 мовних) було залучено 703 особи, було проведено 114 семінарів, 30 конференцій, 16 симпозіумів [5].

Відповідно до рішення Верховної Ради України з 1 вересня 1999 року український контингент миротворчих сил загальною чисельністю 
800 військовослужбовців розпочав практичну діяльність у міжнародній миротворчій операції KFOR у Косово. Було усунено одну із перешкод, коли парламент України в березні 2000 року ратифікував Угоду про статус військ [6]. Це дало змогу військам НАТО тренуватися в Україні на підставі домовленостей та запрошень $\mathrm{i}$, найголовніше, без візових та митних формальностей, що затьмарювали попередні навчання. Першими великими навчаннями, на які позитивно вплинули ці домовленості, стали навчання “Cooperative Partner” (18-30 червня 2000 року) за участю понад 4000 військовослужбовців із країн НАТО та держав-партнерів. Друга перешкода зникла, коли парламент дав згоду на розгортання української частини українсько-польського батальйону в польській зоні американського сектору в Косово. Хоча ці сили готувалися разом протягом трьох років, батальйон не мав юридичного статусу в Україні.

Ці приклади дають можливість побачити як впливав процес формування нормативно-правової бази на розвиток воєнно-політичного співробітництва. У період з 2000 до 2005 років вона була в основному створена. На жаль, мали місце і негативні рішення, що гальмували процеси співпраці і перешкоджали розвитку ЗС України. Наприклад, заборона парламентом спланованих міжнародних навчань на території України у 2009 році. Щодо “ціни” зірваного депутатами Верховної Ради міжнародного навчання “Сі бриз -2009” свідчать такі втрачені можливості для ЗС України: 14 плавзасобів українського флоту мали пройти 7 тисяч морських миль; не довелось військовим морякам виконати ракетно-артилерійські стрільби та інші бойові вправи; екіпажі вертольотів і літаків не змогли збільшити свій наліт на кожний літальний апарат; підрозділи морської піхоти та аеромобільних військ не виконали близько 500 стрибків із парашутом, у тому числі з літака військово-повітряних сил Бундесверу; не відбувся черговий етап державних випробовувань військово-транспортного літака Ан-70 (планувалось продемонструвати його ефективність потенційним покупцям із іноземних держав; під час маневрів із борту літака передбачалось виконати 
понад 400 стрибків із парашутом) [7]. Головні витрати по організації навчань брали наші партнери - США і НАТО.

Досягненню позитивних результатів сприяла діяльність органів управління, відповідальних за здійснення міжнародного військового співробітництва взагалі і безпосередньо з НАТО. До органів міжнародного співробітництва належали: Департамент міжнародного оборонного співробітництва МОУ; Управління військового співробітництва та Управління євроатлантичної інтеграції ГШ ЗСУ; управління та відділи міжнародного співробітництва командувань видів Збройних Сил; відділи (відділення, групи) інших структурних підрозділів Міністерства оборони та органів військового управління Збройних Сил, до основних функцій яких належало здійснення міжнародного співробітництва. Орган, що відповідав безпосередньо за співробітництво з НАТО, у структурі Генерального штабу ЗС України було створено в 2003 році. Це було Управління євроатлантичного співробітництва (з 2004 р. - Управління євроатлантичної інтеграції; 3 2010 року - Головне управління військового співробітництва та миротворчих операцій.

У процесі розвитку відносин з Альянсом, визначених вище перших трьох етапів, було започатковано широкий набір дієвих механізмів військового співробітництва. У рамках реалізації особливого партнерства між Україною і НАТО були сформовані:

\section{інструментарій співробітництва:}

Комісія Україна - НАТО (КУН) - найвищий орган, що ухвалював рішення стосовно розвитку відносин Україна - НАТО та спрямовував заходи в плані практичного співробітництва; форум для консультацій між країнамичленами Альянсу та Україною з тих питань безпеки, що викликали обопільну зацікавленість (засідання щороку на рівні глав держав, міністрів закордонних справ і міністрів оборони). КУН постійно аналізувала заходи співробітництва, що розроблялися у рамках участі України в програмі НАТО “Партнерство заради миру”, а також у галузі безпосередньої військової співпраці, що 
виконувалася відповідно до Річних робочих планів у форматі Військовий комітет Україна-НАТО.

Військовий комітет Украӥна - НАТО як орган робочих консультацій з суто військових питань (у форматі “29+1” на рівні начальників генеральних штабів, військових представників). Один із основних інструментів його діяльності - Робочий план (РП). Він затверджувався щорічно та визначав пріоритетні сфери та напрями співробітництва між 3С України та НАТО, включав завдання, спрямовані на підтримку виконання заходів щорічних Цільових планів Україна - НАТО в частині, що стосується Міністерства оборони України.

Спільна робоча група (СРГ) високого рівня з питань воєнної реформи була започаткована з метою виконання Хартії про особливе партнерство Україна - НАТО. Стала постійно діючим механізмом консультацій між Україною та НАТО у форматі “29+1”. Ї̈ї діяльність спрямовувалася на забезпечення підтримки Альянсом процесів оборонної та безпекової сфери держави, насамперед ЗС України у напрямах: виконання військового бюджету; скорочення збройних сил та конверсії; переходу від системи призову до професійної армії; цивільно-військові відносини, підготовка цивільного персоналу. Створений інструментарій співробітництва сприяв практичному виконанню програм та планів співробітництва.

По-друге, дійовим елементом системи співпраці стали плани та програми. Основними з них були: План дій Україна - НАТО і Цільові річні плани (2003-2008 pp., 32009 року - Річна національна програма співробітництва Україна - НАТО, з 2017 року - Річна національна програма під егідою Комісії Україна - НАТО), Індивідуальна програма партнерства між Україною та НАТО, Процес планування та оцінки сил, Концепція оперативних можливостей, Програма НАТО з обміну даними про повітряну обстановку, проєкти Трастових фондів НАТО з питань утилізації надлишкових легкого озброєння, стрілецької зброї та боєприпасів та соціальної адаптації 
військовослужбовців, звільнених 3 військової служби. Розкриємо провідні 3 них.

Аналіз заходів Цільових річних планів показує, що кожен 3 них мав свою направленість на поглиблення співробітництва та відрізнявся відповідними конкретними заходами. У 2003 році - це створення цивільних структур управління в МОУ та участь у миротворчих і гуманітарних операціях під проводом НАТО. У 2004 році найбільш суттєвим було запровадження національної системи оборонного планування відповідно до стандартів НАТО. У 2005 році - забезпечення сумісництва військ (сил), навчання та мовна підготовка, адаптація до цивільного життя звільнених 3 військової служби. У 2006 році - приєднання до антитерористичної операції в Середземному морі “Активні зусилля”, вирішено питання щодо участі військово-транспортної авіації України в операціях НАТО та активізація двосторонніх відносин. У 2007 році - спрямування близько 100 заходів на реалізацію пріоритетних завдань Державної програми розвитку ЗС України. У 2008 році - підготовка до участі та проведення спільних повітряних операцій із країнами-членами НАТО; підготовка підрозділів ЗС України до дій у складі Багатонаціональних сил. Україна була єдиною країноюпартнером, що брала участь у всіх операціях НАТО. У 2009 році - подальша професіоналізація ЗС України (зокрема створення професійного сержантського корпусу), підготовка цивільного персоналу для сектору безпеки.

Щорічна Індивідуальна програма партнерства (ІПП) - була складовою частиною щорічного Цільового плану Україна - НАТО та використовувалася для індивідуальної підготовки офіцерів та працівників ЗС України за різними напрямами та спеціальностями. Вона традиційно включала декілька сотень заходів. Переважну кількість заходів складали курси фахової підготовки (з 1994 року по 2009 рік в країнах-членах НАТО пройшли підготовку 8,5 тисяч українських офіцерів). На кінець 2009 року представники ЗС України навчались у 22 країнах світу. 32006 року на мовних курсах за 
кордоном почали проходити підготовку цивільні працівники, а з 2007 року рядовий, сержантський та старшинський склад [8]. У цілому, ІПП стала одним із механізмів сумісності із збройними силами країн-членів НАТО та реалізації визначених завдань у галузі безпеки і оборони.

Таким чином, за період з 1991 по 2009 рр. воєнно-політичне співробітництво Збройних Сил України 3 НАТО набуло системного характеру. Щорічно проводилось близько 500 заходів по співпраці, спрямованих на підтримку виконання пріоритетних завдань розвитку ЗС України, 5000 військовослужбовців щорічно залучалися до заходів міжнародного військового співробітництва. За період 1995-2009 років ЗС України взяли участь у 150 міжнародних навчаннях. Разом з тим суттєвою проблемою залишалось недостатнє фінансування. Тільки у період з 2006 по 2009 рік оборонне відомство недоодержало близько 11,5 млрд грн.

Оцінюючи етап конструктивного співробітництва з НАТО з 2010 року, експерти Центру Разумкова вважають, що попри односторонню відмову України від кінцевої мети - набуття повноправного членства в цій організації, формат та інструменти співпраці практично не зазнали змін. Приймалися Річні національні програми, діють КУН, Офіс зв'язку НАТО, Центр інформації і документації НАТО, інші сформовані на попередніх етапах структури, що свідчить про взаємний інтерес до збереження співробітництва. На державному рівні було проведено ряд організаційних змін. Президент реформував систему національних координаторів 3 питань партнерства України з НАТО, створивши комісію, що стала координуючим органом у міжвідомчій системі співробітництва 3 Альянсом. Без проблем проходили майже всі заплановані зустрічі, парламент кожен рік підтверджував рішення про допуск іноземних підрозділів на територію України для участі у міжнародних військових навчаннях. Акцентується увага на тому, що Президент підписав указ "Про участь Збройних сил України в багатонаціональних військових формуваннях високої готовності”, відповідно до якого наші підрозділи братимуть участь у силах реагування 
НАТО. При цьому експерти виділяють такі ключові аспекти практичного співробітництва України і Альянсу:

по-перше - участь України в місіях НАТО (йдеться про Косово, Ірак, Афганістан, антитерористичну операцію “Активні зусилля” у Середземному морі), особлива увага звертається на те, що українські літаки і корабель “Костянтин Ольшанський” евакуювали іноземних громадян з Лівії. Участь у цих операціях НАТО сприяла збройним силам досягти взаємосумісності 3 арміями країн-членів Альянсу.

по-друге - співробітництво у військовій сфері і реформуванні сектору безпеки та оборони. Тут необхідно сказати про реалізацію програми зі знищення в Україні надлишкової кількості звичайних боєприпасів, стрілецької зброї і легкого озброєння, про обмін даними, що стосуються повітряної обстановки між Україною і сусідніми країнами-членами Альянсу (зокрема Туреччиною), а також про перспективи участі нашої країни в силах реагування НАТО. Зроблені конкретні кроки у військово-технічній сфері співробітництва. Так, при будівництві пріоритетного для нашої країни корабля класу “корвет”, церемонія закладання якого відбулася в Миколаєві, натовські комплектуючі мають становити вагому частину $-38 \%$.

У 2012 році Збройні Сили України приєдналися до Ініціативи поєднаних сил (Connected Forces Initiative). Головною метою зазначеної ініціативи є покращання взаємосумісності та підвищення здатності збройних сил Альянсу i партнерів діяти разом при виконанні завдань у багатонаціональних операціях. Це дало змогу посилити підготовку військ (сил) та індивідуальну підготовку особового складу 3 максимально ефективним використанням тренувальних інституцій НАТО та центрів досконалості; збільшити кількость військових навчань, особливо за участю СРН; більш ефективно використовувати сучасні технології для полегшення досягнення взаємосумісності та інтеграції необхідних спроможностей.

Хоча зміна зовнішньополітичної стратегії, як вважають експерти, “не загальмувала динаміки нашого співробітництва з Альянсом, а лише додала 
йому прагматизму і конструктивності”, але це справедливо тільки щодо сфери військового співробітництва. Відсутність прогресу в дотриманні ідеологічно-ціннісних принципів, якими керуються країни НАТO, продовжується і сьогодні. Це стосується виконання таких пунктів Річної національної програми співробітництва України - НАТО як “Внутрішня політика” (підпункти “Демократичні реформи” і “Забезпечення верховенства права") та "Економічні питання", де прогресу не спостерігається. Сталою залишається тенденція недофінансування 3С України. Оборонний бюджет України з фактично 180-тисячним військом у 2012 р. склав 16,4 млрд грн, що становить близько 2 млрд дол. Це менше, ніж, наприклад, Румунія витратила у 2010 р. (2,11 млрд дол.) при чисельності армії у 73 тис. осіб. У 2013 році на закупівлю нових зразків зброї оборонним бюджетом передбачалось 900 млн грн. Мінімальна ж потреба складає не менш 500 млн дол. щороку [9].

У 2014 році Збройні Сили України приєдналися до Ініціативи взаємосумісності партнерів (Partnership Interoperability Initiative). Ініціатива була започаткована з метою збереження та подальшого розвитку операційної взаємосумісності держав-членів та партнерів НАТО після завершення операції Альянсу в Афганістані. Ініціатива передбачає надання допомоги 3 розвитку, диверсифікації, а також збільшення переліку партнерських сил та засобів, що сертифіковані та готові брати участь у операціях під проводом Альянсу та СРН. Досягнення партнерами взаємосумісності з НАТО у рамках зазначеної ініціативи здійснюється у трьох вимірах: технічна, операційна та доктринальна взаємосумісність.

Анексія Криму, окупація частини Донбасу та війна з Росією на Сході України надали ідеї вступу до НАТО нового звучання. Якщо до подій 2014 р. більшість населення була переконана, що можлива інтеграція до Атлантичного договору може мати негативні наслідки для країни, то тепер, за результатами останніх соціологічних досліджень, більша частина українців підтримує двосторонні відносини і не проти подальшого приєднання України до блоку НАТО (у 2012 р. 62\% українців не хотіли 
вступати в НАТО (тільки 15\% - “за”), у березні 2014 р. ситуація кардинально змінилася - 47\% українців виступали “за” і стільки ж “проти”, найменше “проти” було в серпні 2014 р. - 19\% і 52\% “за”).

Наприкінці грудня 2016 р. Фонд “Демократичні ініціативи” ім. Ілька Кучеріва та Центр ім О. Разумкова оприлюднили дані, що переконливо вказують на успішність референдуму щодо членства України в НАТО в разі його проведення найближчим часом: 3 62\% українських громадян, які взяли би у ньому участь, абсолютна більшість - 72\% - однозначно підтримала би членство в Альянсі. Про це заявила на брифінгу 2 лютого 2017 р. директор “Демініціатив” І. Бекешкіна і 8 червня 2017 року саме це стало запорукою внесення змін до Законів України "Про основи національної безпеки України" та "Про засади внутрішньої і зовнішньої політики України" щодо положень про набуття членства в НАТО як зовнішньополітичний пріоритет України.

Завдання щодо впровадження стандартів НАТО удіяльність Міністерства оборони України та Збройних Сил України, інших складових сил оборони визначені законодавством (Закон України "Про національну безпеку України”) та стратегічними оборонними документами України (Стратегія національної безпеки України, Стратегічний оборонний бюлетень, Воєнна доктрина України тощо).

Впровадження стандарту НАТО передбачає проведення комплексу заходів, що включає прийняття рішення на застосування у Міністерстві оборони України та Збройних Силах України положень (норм, вимог) стандарту НАТО, розроблення на його основі відповідного акта законодавства чи нормативного документа (внесення відповідних змін та/чи доповнень до чинного документа), надання йому чинності у встановленому порядку і його застосування у повсякденній діяльності Міністерства оборони України та Збройних Сил України.

Першочерговість опрацювання стандартів НАТО, з метою прийняття рішення щодо доцільності застосування їх положень (норм, вимог) у 
діяльності Міністерства оборони України та Збройних Сил України, визначена пакетом Цілей партнерства Україна - НАТО, відповідно до якого опрацюванню підлягають 219 стандартів НАТО.

Станом на 01.07.2019 відповідно до Цілей партнерства впроваджено 76 нормативних документів (далі - НД) НАТО (34\% від тих, що підлягають опрацюванню в рамках Цілей партнерства), на основі положень яких розроблено 86 національних та військових нормативно-правових актів і нормативних документів, з них у I півріччі 2019 року впроваджено 21 НД НАТО шляхом розроблення 18 національних військових нормативних документів. Окрім того, у I півріччі 2019 року проводились роботи 3 впровадження стандартів НАТО й поза межами Цілей партнерства. Так, у І півріччі 2019 року впроваджено 7 НД НАТО шляхом розроблення 11 національних військових нормативних документів. Загалом (у рамках досягнення Цілей партнерства та поза ними) впроваджено 220 НД НАТО шляхом розроблення 236 національних та військових нормативно-правових актів та нормативних документів, із них у I півріччі 2019 році впроваджено 28 НД НАТО шляхом розроблення 29 національних військових нормативних документів.

Таким чином, історичний досвід співробітництва України та іiі Збройних Сил з НАТО свідчить про наявність ряду позитивних тенденцій: зростання рівня інтенсивності співпраці; використання створених i формування нових механізмів і програм взаємодії; еволюцію характеру відносин: від початкових форм співробітництва до рівня партнерства i, далі перспективи членства в Альянсі; активізацію співробітництва в напрямах, що безпосередньо впливали на розвиток ЗС України. У процесі співпраці ЗС України 3 Альянсом сформувалася ефективна система, що сприяла підвищенню боєздатності частин і підрозділів, професіоналізму керівного складу різних категорій, виконанню різноманітних завдань із урахуванням сучасного рівня підготовки збройних сил наших партнерів. 
Разом $з$ тим події на Сході України показали, що в умовах сьогодення існує багато проблем у підготовці і забезпеченні ЗС України, особливо воєнно-технічної складової. Постало питання про необхідність безпосередньої допомоги з боку країн-членів Альянсу в оснащенні наших бойових частин сучасним озброєнням. Це питання порушувалося на Уельському саміті НАТО, що знайшло розуміння і зумовило конкретні дії 3 боку країн-партнерів. Члени Північноатлантичного альянсу започаткували нові програми, так звані трастові фонди, зосереджені на командуванні, управлінні, зв’язку, логістиці, стандартизації, кіберзахисті, військовій професіоналізації. Для реалізації цих програм прийнято рішення виділити 15 млн євро [10]. У реформуванні оборонного сектору України братимуть участь кваліфіковані радники 3 країн-партнерів для створення сучасного менеджерського механізму, протидії корупції, посилення спроможності наших збройних формувань. У перспективі співробітництво ЗС України 3 НАТО носитиме більш цілеспрямований характер із урахуванням необхідності оновлення стратегічних цілей і відповідних документів.

\section{Список використаних джерел і літератури}

1. Декларація Варшавського саміту: [Електрон. ресурс]. - Режим доступу : http://www.nato.int/cps/uk/natohq/official_texts_112964.htm?selected Locale $=\mathrm{uk}$

2. Міжнародні відносини i євроатлантичне майбутне України: підручник / Колектив авторів. - К. : ТОВ “Інфодрук”, 2008. - С. 152-153.

3. Співробітництво між Україною і НАТО (поточні питання), (12.01.1994 p. - 28.04.1994 р.). - ГДА МЗС України, ф. 1, оп. 4, спр. 7498, 153 арк.

4. Політика Національної безпеки України в сучасних умовах // Національна безпека і оборона. - 2009. - № 2 (106). - С. 7-20.

5. Документи про розробку Закону України від 2 березня 2000 року "Про ратифікацію Угоди між державами-учасницями Північноатлантичного 
Договору та іншими державами, які беруть участь у програмі “Партнерство заради миру” щодо статусу їхніх збройних сил та Додаткового протоколу до цієї Угоди), (текст Закону, подання Президента України, висновок, стенограма), (09.09.1998-02.03.2000рр.). - Архів Верховної Ради України, ф. 1 , оп. 22, спр. 6026, 78 арк.

6. Довідник з питань міжнародного військового співробітництва. - К. : “МП Леся", 2003. - С. 177-181.

7. Всеукраїнська громадська політична газета “Демократична Україна”. - 28 травня 2010 року. - № 21.

8. Інформаційні матеріли Департаменту кадрової політики МОУ щодо кадрового забезпечення заходів міжнародного співробітництва у ЗСУ: [Електрон. ресурс]. - Режим доступу: http://www.mil.gov.ua/index.php? part=education\&sub=zag_har\&lang=ua

9. Костюк П. Збройні Сили України: у пошуках нитки Аріадни?: [Електрон. ресурс]. - Режим доступу : http://www.universum.lviv.ua/ journal/2013/6/zsu.htm

10. Країни НАТО нададуть Україні додаткову допомогу в 15 млн євро: [Електрон. pесурс]. - Режим доступу: http://ukr.segodnya.ua/print/ politics/pnews

11. Закон України "Про засади внутрішньої і зовнішньої політики" №2411-VI від 1.07.2010 р. (зі змінами) // Відомості Верховної Ради України, 2018. - № 31. - ст. 241.

12. Конституція України (зі змінами згідно із Законом України № 2680VIII від 7.02.2019). 
Derikot O.Yu., Senior Lecturer of Department of Strategy of National Safety and Defensive of Ivan Cherniakhovskyi National Defence University of Ukraine (Kyiv);

Klymenko V.S., Candidate of Political Sciences, Associate Professor, Associate Professor of Department of Strategy of National Safety and Defensive of Ivan Cherniakhovskyi National Defence University of Ukraine (Kyiv);

Kozinets I.P., Candidate of Historical Sciences, Senior Researcher, Professor of Department of Strategy of National Safety and Defensive of Ivan Cherniakhovskyi National Defence University of Ukraine (Kyiv)

\section{COOPERATION BETWEEN THE ARMED FORCES OF UKRAINE AND NATO: EXPERIENCE FROM THE PAST AND PROSPECTS FOR THE FUTURE}

In the article the authors disclosed the slavery of the Armed Forces of Ukraine with NATO at each of the recognized stages of NATO. The legal framework for cooperation with the Alliance is analyzed and the positive character of military-political cooperation in the interests of international security is revealed.

Keywords: Armed Forces of Ukraine, NATO, cooperation, non-aligned status, Euro-Atlantic integration, Partnership for Peace. 